\title{
History of the Department of Surgery at the University of Toronto: celebrating a centennial of progress and innovation
}

\author{
Robin McLeod, MD \\ Shaf Keshavjee, MD \\ Najma Ahmed, MD \\ Robin Richards, MD \\ Michael G. Fehlings, MD, PhD \\ Avery Nathens, MD, PhD \\ Ori D. Rotstein, MD \\ James T. Rutka, MD, PhD
}

Accepted November 22, 2021

\section{Correspondence to: \\ J. Rutka \\ Department of Surgery, 5th Floor \\ 149 College St \\ Toronto ON M5T 1P5 \\ james.rutka@utoronto.ca}

Cite as: Can J Surg 2022 February 3; 65(1). doi: 10.1503/cjs.013621

\begin{abstract}
SUMmarY
Now in its centennial year since inauguration, the Department of Surgery at the University of Toronto lays claim to more than 500 faculty, 270 residents, and 250 clinical fellows. There are 7 direct entry residency training programs, and 4 subspecialty programs accredited by the Royal College of Physicians and Surgeons of Canada. There have been 10 chairs of the department since 1921 . This article chronicles the life and times of the previous chairs in sequence; the success of the department originates from its many talented and luminary surgeons who have innovated and shaped their fields of surgery. In recent years, the department's academic productivity has been characterized by more than 1400 peer-reviewed publications per year, and annual research grant capture in excess of $\$ 90$ million. Since the time of William Gallie, surgical trainees have been enabled to develop careers in surgery and science through the Gallie Program and, more recently, the Surgeon Scientist Training Program (SSTP) to attain higher graduate degrees. Providing quaternary surgical care at multiple hospital sites in Toronto, the Department of Surgery takes great pride in its robust clinical fellowship programs across all specialties that continue to attract trainees from around the world.
\end{abstract}

T he tradition of surgery in Toronto dates back to the founding of the University of King's College Medical School in 1843, but scant details are available from that time. Early steps toward the formal organization of surgery as a discipline were made in 1887 with the passing of the University Federation Act and the establishment of the Faculty of Medicine. At that time, William T. Aikins, dean of the medical school, was designated the first professor of surgery, a position he held for 10 years. ${ }^{1}$ He was followed in this position by Irving Heward Cameron, who was professor of surgery from 1897 to 1920. During this time, a notable figure in the history of surgery at the University of Toronto was George Armstrong Peters, who served in the Department of Surgery from 1892 to 1907 and who was professor of surgery from 1903 to $1907 .{ }^{2}$ He developed surgical techniques for thyroidectomy for exophthalmic goiter and ectopia vesicae. In his name, a junior faculty award has been given since 1912 to a talented academic surgeon, typically within the first 5 years of appointment (https://surgery.utoronto.ca/gallie-day-award-recipients).

\section{Clarence Starr (chair, 1921-1929)}

In 1921, in response to a generous $\$ 1 \mathrm{M}$ grant from the Rockefeller Foundation, a formal Department of Surgery was established, and the first chair of this department was Clarence Starr, who also worked as surgeon-in-chief at the Toronto General Hospital (TGH) ${ }^{3}$ (Figure 1). It should also be mentioned that at about this time, Frederick Banting, a surgical trainee in orthopedics from the University of Toronto, set about to change the world through his and Charles Best's experimentation on the endocrine pancreas, leading to the discovery of insulin and its use in the treatment of human diabetes mellitus. ${ }^{4}$ Banting had been trained by Starr in orthopedics at the 


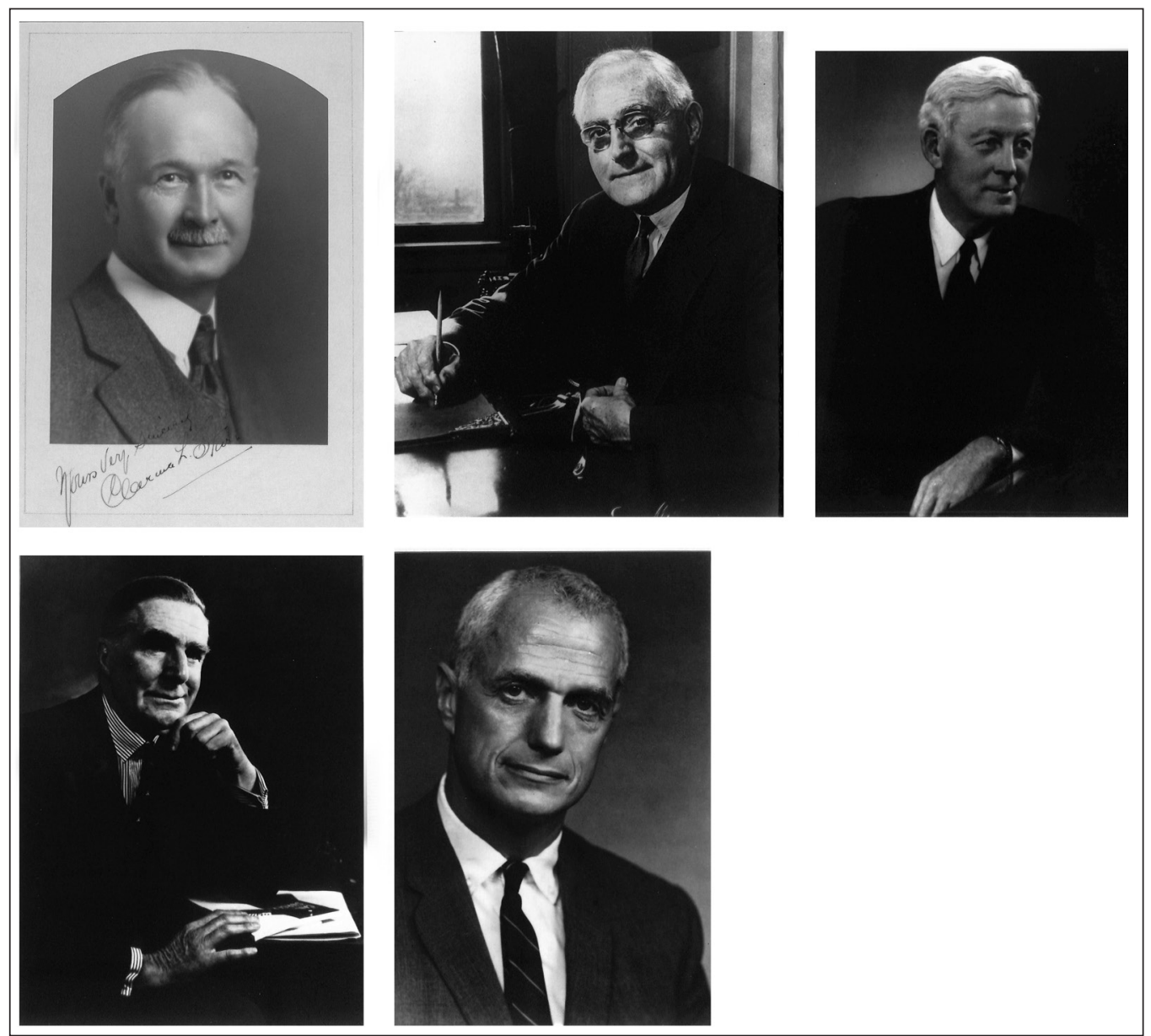

Fig. 1. First 5 professors and chairs of the University of Toronto Department of Surgery from 1921 to 1972, and their terms of service. Top row: Clarence Starr (1921-28), William E. Gallie (1929-46) and Robert Janes (1947-57). Bottom row: Frederick Kergin (1957-66) and William Drucker (1966-72). The portraits hang in the Department of Surgery office.

Hospital for Sick Children. After a short sojourn in London, Ontario, as a general practitioner and surgeon, ${ }^{5}$ Banting returned to Toronto and convinced John James Rickard Macleod, professor of physiology, that he could perform surgery to ligate the pancreatic ducts in dogs and to isolate the factor from the surviving pancreatic islets that controls diabetes. Upon the purification of "insulin" with the assistance of Dr. James Collip, a biochemist from the University of Alberta, Leonard Thompson, age 14, became the first patient with diabetes to be treated by Banting at the Toronto General Hospital using a purified insulin preparation with encouraging results. ${ }^{4}$ Just as the year 1921 is important for the establishment of the first professor and chair of the Department of Surgery at the University of Toronto, Clarence Starr, it also marks the discovery of insulin by Sir Frederick Banting, whose surgical skills were critical in his experimental approach and success.

Starr served as professor of surgery for 8 years. He had served as the president of the American Orthopaedic Association in 1920, and vice-president of the American Surgical Association (ASA) in 1928. He was a skillful adminis- trator, and made lasting contributions to the world literature on the management of hematogenous osteomyelitis. ${ }^{3} \mathrm{He}$ died in 1928 at age 60 from a myocardial infarction and was succeeded by Dr. William Gallie in 1929.

Roscoe Reid Graham was a rising star surgeon during Starr's tenure as professor of surgery. He was among the first to successfully enucleate an insulinoma, to treat patients with iodine for chemical thyroidectomy, and to develop a specific surgical procedure for ruptured perforated ulcer disease using an omental patch repair known as the "Graham patch." 6,7 In 1932, at age 42, Graham became the youngest surgeon ever to be elected as a fellow to the ASA. ${ }^{7}$ He served as vice-president of the ASA in 1939, and editor of the Annals of Surgery thereafter.

During Starr's tenure as chair, surgery on the nervous system was initiated in Canada in 1923 by Kenneth George McKenzie, who had spent the prior year training under the tutelage of Harvey Cushing in Boston on a Charles Mickle Fellowship. ${ }^{8}$ McKenzie led the Division for almost 30 years, before he was succeeded by Harry 


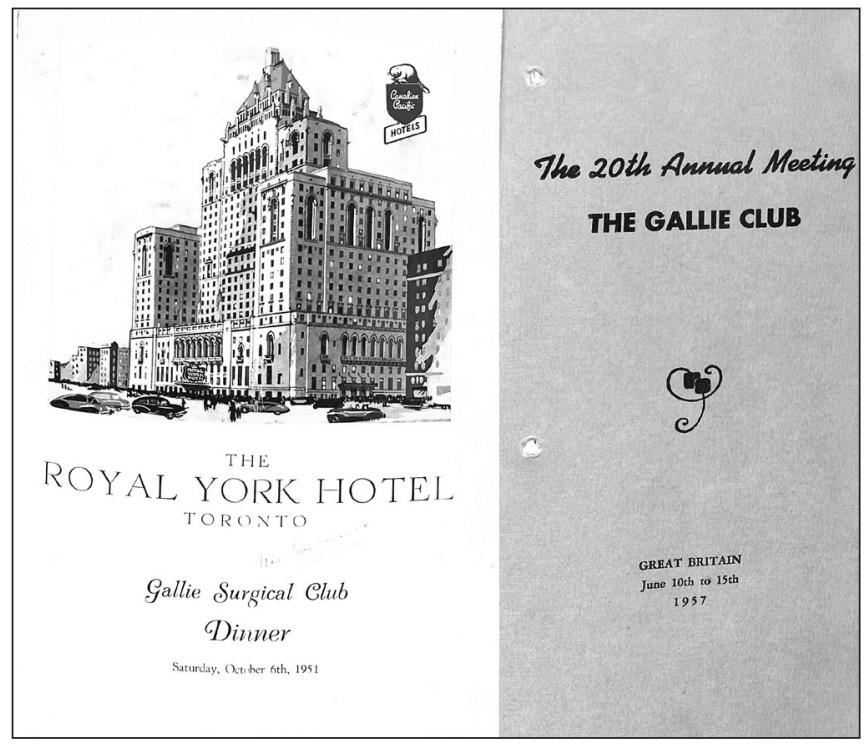

Fig. 2. Left: Front page of Gallie Surgical Club Dinner program, Royal York Hotel, Toronto, 1951. Right: Front cover of the 20th Annual Gallie Club Meeting program in Great Britain, June 10-15, 1957.

Botterell who served in the role from 1952 to 1962 . McKenzie worked diligently, almost in isolation, for more than 15 years before the neurosurgery program was given priority status at the Toronto General Hospital. ${ }^{9,10} \mathrm{He}$ developed pioneering neurosurgical techniques for spasmodic torticollis, and performed the first hemispherectomy in the world on a teenager with epilepsy, who survived without seizures and lived productively for 20 years thereafter. ${ }^{11}$ Wise succession planning in the appointment of the subsequent chairs of the Division of Neurosurgery after Botterell has led to this surgical specialty becoming one of the largest and most influential programs of neurosurgery in the world to this day. Global neurosurgical impact has been realized through the clinical and research talents of Ronald Tasker and Andres Lozano in functional neurosurgery; Bruce Hendrick, Harold Hoffman, and Robin Humphreys in pediatric neurosurgery; Charles Tator and Michael Fehlings in spinal cord injury; and William Lougheed in vascular neurosurgery.

\section{William Gallie (ChaiR, 1929-1946)}

A native of Barrie, Ontario, Gallie graduated from the Faculty of Medicine at the University of Toronto in 1903. His training at The Hospital for Sick Children and subsequently the Toronto General Hospital was heavily influenced by Starr and Peters. Gallie devoted his early faculty appointment years to clinical research and published numerous papers on stabilizing paralytic feet, the use of bone grafts in orthopedics, and transplanting fascia and tendons for orthopedic injuries. ${ }^{12-15} \mathrm{He}$ was surgeon in chief at The Hospital for Sick Children from 1921 to 1929. Following Starr's passing, Gallie reorganized the university program in surgery and brought much needed uniformity of training to the different hospitals (Figure 1). He was also the first to put specialty care surgical patients on wards to be looked after by specialists. ${ }^{16}$ Early in Gallie's tenure as chair, the Department of Surgery moved its offices to the Banting Institute upon its opening on Sept. 16, 1930, where it remained until 2013 when it moved to its current location on the 5 th floor of the Stewart Building.

One of Gallie's lasting contributions was the establishment of the "Gallie Course" in surgery, which provided programmatic training for a select group of surgical trainees. In this 3 -year course, the trainees would spend 2 years on surgical services: the first year in general surgery, and the second year divided into 6-month rotations in urology, neurosurgery or pediatric surgery. ${ }^{17}$ The course also included 6 months in medicine and 6 months in pathology, with emphasis on surgical research performed during these rotations. The completion of the course would be followed by the certification examinations in surgery administered by the Royal College of Physicians and Surgeons of Canada. The Gallie Course started on July 1, 1931, with 3 residents per year. The "Gallie Club" was formed in 1937 and comprised all past and current trainees of the Gallie Course. The Gallie Club met almost every year thereafter until 1975 (Figure 2). During Gallie's lifetime, 72 trainees completed the Gallie Course. ${ }^{17}$

During Gallie's tenure as chair, the Division of Orthopedic Surgery was established in 1939 by Robert Inkerman Harris, with a legitimate training program beginning in 1951 under Frederick Dewar. Luminaries who worked within the division since its founding included Ian MacNab, Walter Bobechko, and John Kostuik in spinal orthopedics; David MacIntosh in orthopedic sports medicine; Robert Jackson in arthroscopy; and Robert Salter and Mercer Rang in pediatric orthopedics. ${ }^{1}$

While urological procedures had been performed since 1922 in the first urology service established in Canada under W. Warner Jones, it was not until 1947 that James McLelland, founder of the Canadian Urological Association, became the first professor of urology at the University of Toronto. He was followed in sequence by Carl Aberhardt; Charles Robson, who pioneered radical thoracoabdominal nephrectomy; Andrew Bruce, who was among the first to study the use of Bacillus CalmetteGuérin immunotherapy (BCG) for bladder cancer; and Michael Jewett, who had a specialty focus in uro-oncology. ${ }^{1}$

Gallie served as dean of the Faculty of Medicine from 1936 to 1946 . During that time, he was also president of the American College of Surgeons for an unprecedented 6-year term during World War II. Gallie stepped down as professor of surgery at the University of Toronto in 1947. He became president of the ASA in 1948. Later in his career, Gallie was able to convince R. Samuel McLaughlin, 


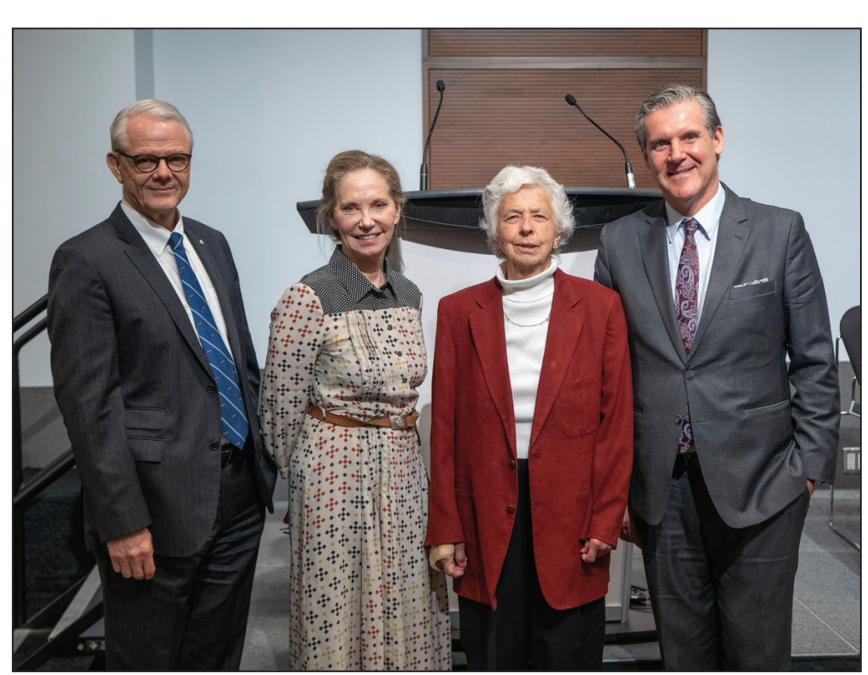

Fig. 3. 2018 Gallie Day Gordon Murray Lectureship. Left to right: James Rutka, RS McLaughlin chair; Susan E. Mackinnon, Sydney M. and Robert H. Shoenberg professor, surgery, Washington University, and University of Toronto alumna, Department of Surgery, Gordon Murray Lecturer; Rosalind Bradford, daughter of Gordon Murray; and Michael Fehlings, vice chair research, Department of Surgery. Photo courtesy of Mr. Diogenes Baena, Hospital for Sick Children.

president of General Motors Canada, to donate substantial funds to establish a foundation to support advanced postgraduate studies for trainees in surgery. ${ }^{18}$ Since the establishment of this fund in 1951, more than 300 surgeons have taken advantage of these "McLaughlin scholarships." Productive and active in life almost to the end, Gallie died in 1959 from disseminated squamous cell carcinoma from a tooth socket. In Gallie's name and honour, the Department of Surgery celebrates "Gallie Day," established in 1974 as an annual event to celebrate and highlight the accomplishments of surgical residents in the Surgeon Scientist Training Program (SSTP) pursuing graduate degrees. Upon Gallie's passing, McLaughlin endowed the "Gallie Lecture" with the Royal College of Physicians and Surgeons of Canada, which is now presented at the Canadian Surgery Forum. ${ }^{18}$ Gallie was named to the Canadian Medical Hall of Fame in 2001.

During Gallie's tenure as professor of surgery, Donald Walter "Gordon" Murray, a surgeon appointed to the Toronto General Hospital became known as one of Canada's greatest surgical pioneers. ${ }^{19}$ Murray was among the first to perform internal stenting of obstructing esophageal cancer ${ }^{20}$ and bone autotransplantation for malunion of the scaphoid, ${ }^{21}$ and to study the use of heparin in vascular surgery in humans to prevent thrombosis after arterial embolectomy and cardiac valve surgery..$^{22}$ Murray also invented a renal dialysis machine and purified anticancer sera to treat patients with cancer, foreshadowing the field of immunotherapy. ${ }^{19,23}$ In Murray's name and honour, the Gordon Murray lectureship was established in the Department of Surgery in 2004 to honour an international luminary in surgery (Figure 3 and Table 1).

\section{ROBERT JANES (CHAIR 1947-1957)}

Gallie was succeeded by Robert Meredith Janes, who served as professor of surgery from 1947 to 1957 (Figure 1). Janes was considered an outstanding thoracic surgeon and surgeon educator. He was a founding member of the American Board of Thoracic Surgery in 1948, and became president of the American Association for Thoracic Surgery (AATS) in 1953. Born on a small farm in Lambton County, Ontario, Janes did his early surgical training at The Hospital for Sick Children and at St Bartholomew's Hospital in the United Kingdom. Together with his close surgical colleague and friend at the Toronto General Hospital, Norman Shenstone, he invented the lung tourniquet used to help facilitate lobar resections. ${ }^{24}$ After World War II, Janes encouraged new faculty members in surgery to pursue research activities and further supported the surgeon-scientist paradigm at the University of Toronto. Janes also coordinated the rotations of surgical trainees at the 4 main teaching hospitals. ${ }^{25}$

Just as there was a "Gallie Club" of former trainees of William Gallie, so there was the "Janes Society" formed in 1955, comprising a group of Janes' trainees from 1943 to 1953 , totaling some 114 members (Figure 4). The tenth anniversary meeting of the Janes Society took place on the occasion of Dr. Janes' 70th birthday in 1964, in Glasgow, Edinburgh, and London, with dinner at the Royal College of Surgeons in London. Janes retired from surgical practice in 1964 at age 70 , but was still active in steering surgical services at the Humber Memorial Hospital and at the newly formed North York General Hospital. Janes was notable for being kind, gentle, unselfish, loyal to ideals, a revered teacher, brilliant surgeon, and a fine gentleman. ${ }^{24}$

During Janes' tenure as professor and chair of surgery, notable leaders in cardiac surgery included William Gordon Bigelow, who was instrumental in developing the first artificial heart pacemaker and pioneered the use of hypothermia in heart surgery; ${ }^{26}$ and William T. Mustard, who developed a congenital heart operation to repair transposition of the great vessels to salvage children with "blue baby syndrome."27

\section{Frederick Kergin (CHAIR, 1957-1966)}

Frederick Kergin succeeded Janes and served as chair of the Department of Surgery from 1957 to 1966 (Figure 1). Kergin was born in Port Simpson, British Columbia. Following his early education in British Columbia, Kergin came to the University of Toronto to study biology and then medicine. He graduated from medical school in 1930. In 1931, he became a Rhodes Scholar and spent 2 years at Oxford University. In 1933, he joined the Gallie Course, and was certified by the Royal College of Physicians and Surgeons of Canada in 1939. During 


\section{Table 1. Annual Gordon Murray Lecturers at Gallie Day, 1981-2021}

\begin{tabular}{|c|c|c|}
\hline Year & Lecturer & Institution \\
\hline 1981 & Dr. Raymond O. Heimbecker & University of Toronto \\
\hline 1982 & Dr. E. Stanley Crawford & Baylor College of Medicine, Texas Medical Center, Houston, Texas \\
\hline 1983 & Sir Roy Yorke Calne & Cambridge University, Cambridge, United Kingdom \\
\hline 1984 & Dr. Charles G. Drake & University of Western Ontario, London, Ontario, Canada \\
\hline 1985 & Dr. Judah Folkman & Boston Children's Hospital, Boston, MA USA \\
\hline 1986 & Dr. Thomas E. Starzl & University of Pittsburgh, Pittsburgh, Pennsylvania USA \\
\hline 1987 & Dr. Martin Allgöwer & University of Basle, Basle, Switzerland \\
\hline 1988 & Dr. Joel D. Cooper & University of Pennsylvania, Philadelphia, Pennsylvania USA \\
\hline 1989 & Dr. Michael R. Harrison & Children's Hospital, University of San Francisco, San Francisco, CA USA \\
\hline 1990 & Dr. D. Eugene Strandness & Universityof Washington, Seattle, Washington, USA \\
\hline 1991 & Dr. Richard L. Simmons & University of Pittsburgh, Pittsburgh, Pennsylvania \\
\hline 1992 & Dr. Bryce Weir & University of Calgary, Calgary, Alberta, Canada \\
\hline 1993 & Dr. Jonathan L. Meakins & McGill University, Montreal, Quebec, Canada \\
\hline 1994 & Col. Basil A. Pruitt Jr. & University of Texas Health, San Antonio, Texas \\
\hline 1995 & Dr. Samuel A. Wells Jr. & Duke University Medicine Center, Durham, North Carolina USA \\
\hline 1996 & Dr. Douglas Wilmore & Harvard Medical School, Boston, MA USA \\
\hline 1997 & Dr. J. Roland Folse & University of Washington School of Medicine, Seattle, Washington USA \\
\hline 1999 & Dr. Alan Hudson & University of Toronto, Toronto, Ontario, Canada \\
\hline 1999 & Dr. Alexander W. Clowes & University of Washington School of Medicine, Seattle, Washington USA \\
\hline 2000 & Dr. E. Darracott Vaughan Jr & Department of Urology at Memorial Sloan-Kettering Cancer Center, New York, NY USA \\
\hline 2001 & Dr. Timothy J. Eberlein & Barnes Jewish Hospital, Saint Louis, Missouri USA \\
\hline 2002 & Dr. Ara Warkes Darzi & Imperial College London, London, England \\
\hline 2003 & Dr. David L. Dunn & University of Minnesota, Minneapolis, Minnesota USA \\
\hline 2004 & Dr. Shafique Pirani & University of British Columbia, Vancouver, British Columbia, Canada \\
\hline 2005 & Dr. David N. Herndon & University of Texas Medical Branch, Shriners Hospital for Children, Galveston, Texas USA \\
\hline 2006 & Dr. Michael L.J. Apuzzo & University of Southern California, Keck School of Medicine, Los Angeles, CA USA \\
\hline 2007 & Dr. Timothy G. Buchman & Emory University School of Medicine, Emery, Saint Louis, Missouri USA \\
\hline 2008 & Dr. Randy N. Rosier & University of Rochester Medical Center, Rochester, NY USA \\
\hline 2009 & Professor Oscar Traynor & Royal College of Surgeons of Ireland, Dublin, Ireland \\
\hline 2010 & Dr. Joseph P. Vacanti & Harvard Medical School, Boston, MA USA \\
\hline 2011 & Dr. Inderbir S. Gill & $\begin{array}{l}\text { USC Institute of Urology, Department of Urology; Keck School of Medicine, University of } \\
\text { Southern California, Los Angeles, California USA }\end{array}$ \\
\hline 2012 & Pr Philippe Menasché & Unité de Chirurgie Cardiaque, Hôpital Européen Georges Pompidou, Paris, France \\
\hline 2013 & Dr. John E. Niederhuber & Johns Hopkins Clinical Research Network, Baltimore, Maryland USA \\
\hline 2014 & Dr. Geoffrey C. Gurtner & Stanford University School of Medicine, Stanford, California USA \\
\hline 2015 & Dr. Clifford Ko & UCLA School of Medicine, Los Angeles, California USA \\
\hline 2016 & Dr. Mohit Bhandari & McMaster University, Hamilton, Ontario, Canada \\
\hline 2017 & Dr. Allan D. Kirk & Duke University School of Medicine, Durham, North Carolina USA \\
\hline 2018 & Dr. Susan E. Mackinnon & Washington University School of Medicine, Barnes-Jewish Hospital, St. Louis, Missouri USA \\
\hline 2019 & Dr. Diane M. Simeone & Perlmutter Cancer Center; New York, New York USA \\
\hline 2020 & Dr. David A. Rogers & University of Alabama, Birmingham, Alabama USA \\
\hline 2021 & Dr. James Shapiro & University of Alberta, Edmonton, Alberta \\
\hline
\end{tabular}

World War II, Kergin served in the Royal Canadian Army Medical Corps, rising to the rank of Lieutenant Colonel. Upon his return to Toronto after the war, Kergin specialized in thoracic surgery and served as head of the "B" service at Toronto General Hospital. ${ }^{1}$

In 1957, Kergin became chair of the Department of Surgery and surgeon-in-chief at Toronto General Hospital. He continued to expand surgical research programs and further developed postgraduate surgical training, with the introduction of various specialties in surgery. In 1966, Kergin became associate dean in the Faculty of Medicine and reorganized the medical undergraduate curriculum. Kergin also led the development of Sunny- brook Hospital into a major teaching hospital. During his career, Kergin was president of the AATS in 1966, and Hunterian professor in the Royal College of Surgeons of England. He also served as chair of the editorial board of the Canadian Fournal of Surgery, and trustee of the RS McLaughlin Foundation. ${ }^{28}$ In his name and honour, the Department of Surgery holds an annual "Kergin Lecture" to invite a wide array of medical and health care experts to speak on a variety of topics (https://surgery. utoronto.ca/kergin-lecturers).

Kergin presided over the establishment of the Division of Plastic Surgery in the Department of Surgery in 1958 by Stuart Douglas Gordon, who became 


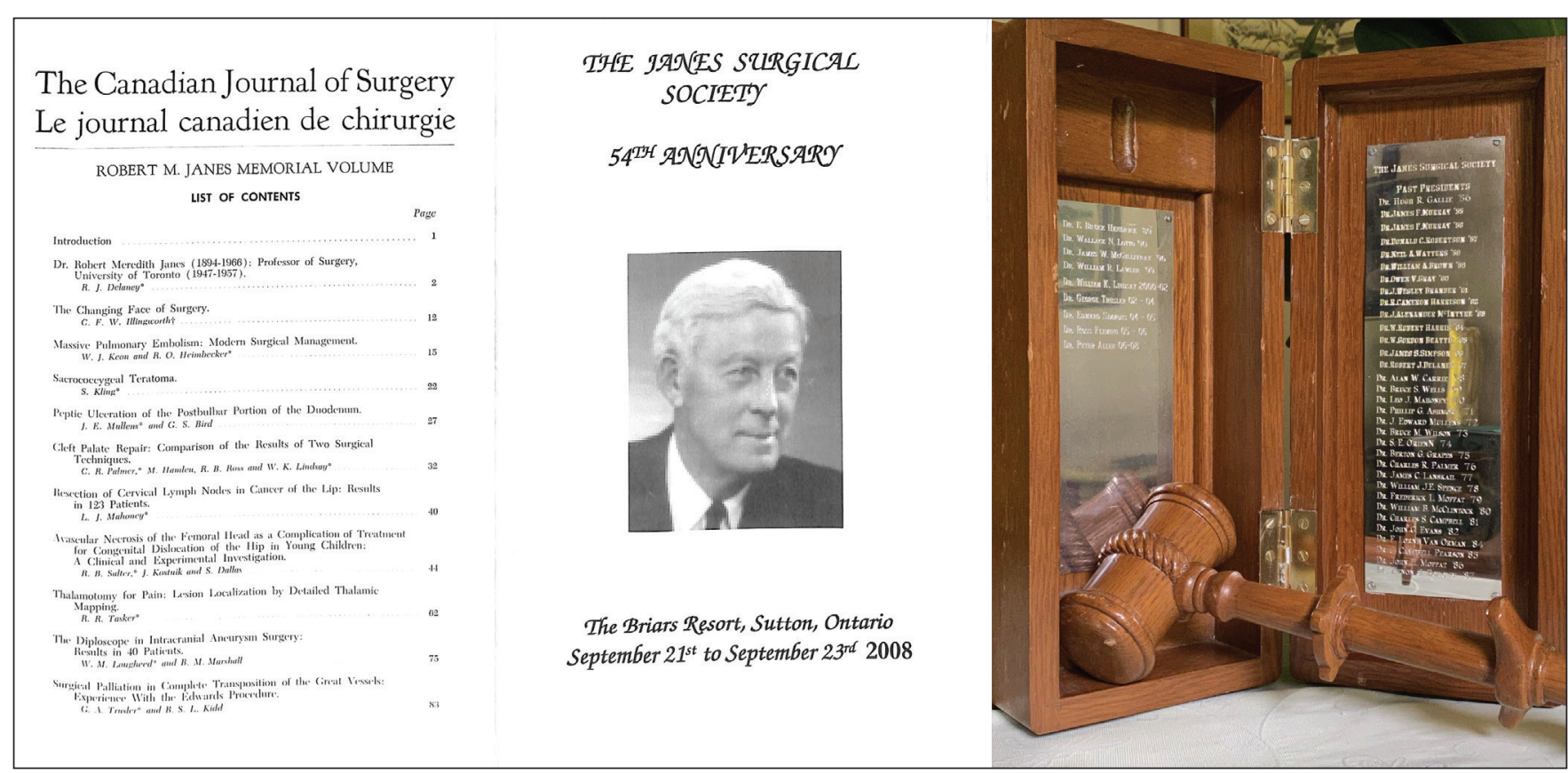

Fig. 4. Left: Memorial tribute issue to Robert Meredith Janes, Canadian Journal of Surgery, 1967. Middle: Program cover of the Janes Surgical Society Annual Meeting and 54th Anniversary, Briars Resort, Sutton, Ontario, Sept. 21-23, 2008. Right: Hand-carved gavel commemorating the past presidents of the Janes Society. The gavel design is based on the lung tourniquet devised by Norman Shenstone and Robert Janes, and carved from an oak bench from the old Toronto General Hospital. It was presented to the Janes Society by Mrs. Lilly Janes in 1967.

internationally renowned for his studies on Dupuytren contracture. Interestingly, plastic surgery can trace its origins in Toronto to 1921, when E. Fulton Risdon performed specialty cases. ${ }^{1}$ Risdon became a founding member of the American Association of Plastic Surgeons. Other notable plastic surgeons in this early era included Ross Tilley in burn surgery; Alfred Farmer, a founding member of the American Society for Surgery of the Hand; and A.B. Le Mesurier, who developed the quadrilateral flap for cleft lip repair.

During Kergin's term as chair, the Division of Cardiovascular Surgery was created with William Bigelow as inaugural head in 1960, to be followed by Ronald Baird in 1977. The Divisions of Cardiac and Vascular Surgery separated in 1981, with Wayne Johnston leading the first Vascular Surgery Division. Cardiac surgery then became a direct-entry 5 -year residency training program in $1994 .{ }^{1}$ Since the creation of a separate Division of Cardiac Surgery, this program has developed world recognition as a centre of innovation and technical excellence, in part through the efforts and impact of Tirone David. ${ }^{29-31}$

\section{William Richard Drucker (ChaiR, 1966-1972)}

The next chair of the Department of Surgery was William Richard Drucker, who served from 1966 to 1972 (Figure 1). Unlike all other chairs in surgery, Drucker was an American who hailed from Case Western Reserve University and was passionate about surgical metabolism and hemorrhagic shock. Under his leader- ship, the undergraduate medical education curriculum was enhanced, and the concept of surgical practice plans was introduced. He also helped to establish Divisions of General Surgery and Thoracic Surgery. The Toronto East General (now Michael Garron Hospital) and St. Joseph's Hospitals became affiliated with the University of Toronto for surgical procedures. ${ }^{1}$ Upon completion of his term as chair, Drucker returned to the United States to become dean of medicine at the University of Virginia in Charlottesville.

While there had been a long history of thoracic surgery procedures being performed in Toronto with the likes of Norman Shenstone, Robert Janes, Harold Wookey, Norman Delarue, Stuart Vandewater and Fred Kergin, it was during Drucker's tenure that the Division of Thoracic Surgery was formally established. In 1967, the Division of Thoracic Surgery formally separated from the Division of Cardiovascular Surgery and formed its own division. ${ }^{32}$ Other notable thoracic surgeons to follow included Griff Pearson, Robert Ginsberg, and Joel Cooper, who were instrumental in performing the first lung transplant in the world in 1983 in a patient who survived long term. ${ }^{32}$ Griff Pearson was a charismatic and innovative thoracic surgeon who attracted many surgeons to come and train in the "Toronto School of Thoracic Surgery." Pearson and his disciples pioneered many surgical techniques in tracheal surgery, esophageal surgery, lung cancer and lung transplantation that have continued to transform the field. This program has trained numerous leaders in thoracic surgery worldwide. 


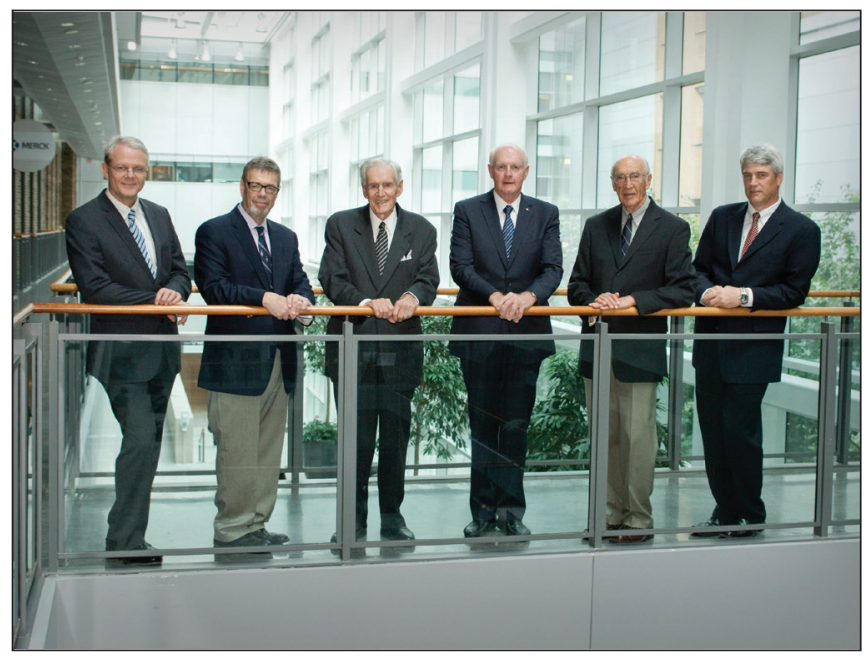

Fig. 5. Professors and chairs of the Department of Surgery from 1973 to 2021, and their terms of service. Left to right: James Rutka (2011-21), Richard Reznick (2002-10), Donald R. Wilson (1972-82), John Wedge (1992-2002), Bernard Langer (1982-92), and David Latter (interim chair 2010-11). Photo courtesy of Mr. Diogenes Baena, Hospital for Sick Children.

\section{Donald R. WILSON (CHAIR, 1972-1982)}

Donald R. Wilson hailed from Saskatoon, Saskatchewan, and was the first chair to serve in the university position from a hospital other than the Toronto General Hospital (Figure 5). Wilson was surgeon-in-chief at the Toronto Western Hospital. He graduated from medical school at the University of Toronto in 1942 and was a trainee in the Gallie Course. He began the process of ensuring that all hospital-appointed surgeons had university appointments. In working with the RS McLaughlin Foundation, Wilson helped to establish the first endowed chair of surgery in Canada, the RS McLaughlin chair. In his name and honour, the Royal College of Physicians and Surgeons of Canada established the Donald R. Wilson Award for Postgraduate Education, and the University Health Network ${ }^{33}$ established the Wilson Centre for medical education. ${ }^{33}$ In 1968, before becoming chair, Wilson led a team of 25 surgeons and associated clinical staff to perform the first heart transplant in Toronto on Pietro Ongaro.

\section{BERNARD LANGER (CHAIR, 1982-1992)}

Bernard "Bernie" Langer followed Wilson in the role of RS McLaughlin chair (Figure 5). Langer graduated from medical school at the University of Toronto, and entered the surgical training program in general surgery, although he professes that his first surgical area of interest was neurosurgery. Langer did postgraduate surgical training in surgical oncology at MD Anderson Cancer Center in Houston, followed by additional fellowship training at the Brigham in Boston in 1962-63. Upon his return to Toronto, there were strong waves of anti-
Semitism preventing many Jewish trainees from receiving positions. Langer was a superb technical surgeon. He completed the first liver transplant in Toronto in 1985 together with gastroenterologist Gary Levy. Together with Steve Strasberg, Charles Tator and Rudolph Falk, Langer established the SSTP, a program in the Department of Surgery that enables surgical trainees to spend focused research time to complete a masters or $\mathrm{PhD} .{ }^{1}$ Funding for the program was derived from the surgical practice plans, and from a variety of postgraduate awards. Langer wanted all trainees to be able to stay in Toronto for their research training, as they would also contribute to the advancement of research in the department. Since its inception, the SSTP has trained more than 450 surgical residents, and the current complement of trainees is 45 residents. ${ }^{34}$ Another one of Langer's major accomplishments was to strengthen and expand the departmental practice plans in order to share and transfer income to support academic activities. It was also Langer's idea to establish different university chairs in the specialties of surgery to serve 5-year terms, renewable once for a total of 10 years. Upon completion of his term as chair, Langer became president of the Royal College of Physicians and Surgeons of Canada, an Officer of the Order of Canada, and an inductee in the Canadian Medical Hall of Fame in 2015. In his and his wife's name and honour, the Division of General Surgery has established the Bernard and Ryna Langer chair in general surgery.

\section{JoHn Wedge (CHAIR, 1992-2002)}

Following Bernie Langer, John Wedge became the next chair of the Department of Surgery and served from 1992 to 2002 (Figure 5). Another chair to hail from Saskatchewan, Wedge rose to the positions of head of orthopedics and then head of surgery at the Royal University Hospital in Saskatoon before coming to Toronto. His area of surgical expertise was in reconstructive surgery of the hip in children. In 1988, he assumed the position of head of orthopedics at the Hospital for Sick Children, and became surgeon-in-chief at the same institution in 1995. Under Wedge's leadership, the Surgical Skills Centre at the Mt. Sinai Hospital was established in conjunction with Zane Cohen, chair of general surgery. ${ }^{1}$ Wedge expanded the recruitment of surgeons to the University of Toronto, and led efforts to support the SSTP. In 1999, the Department of Anatomy and Cell Biology in the medical school became a division in the Department of Surgery where it has remained to this day (https://surgery.utoronto.ca/ about-division-anatomy). Following his term as RS McLaughlin chair, Wedge served as associate dean of clinical affairs in the Faculty of Medicine until 2007. Wedge was named an Officer of the Order of Canada in 2006, and received an honorary degree, Doctor of Laws, from his alma mater, the University of Saskatchewan. 


\section{RICHARD REZNICK (CHAIR, 2002-2010)}

Richard Reznick served as RS McLaughlin chair from 2002 to 2010 (Figure 5). Reznick trained initially at McGill University before coming to Toronto to complete his residency in general surgery. Unlike previous RS McLaughlin chairs, Reznick sought advanced training in surgical education from Southern Illinois University followed by a fellowship in colorectal surgery at the University of Texas in Houston. He pioneered the Objective Structured Clinical Examination (OSCE) that is the standard examination used each year to assess medical licensure applicants in Canada. Reznick was the inaugural director of the Wilson Centre for medical education at UHN. ${ }^{1}$ During his tenure as RS McLaughlin chair, Reznick bolstered recruitment processes in the Department of Surgery, he ensured all faculty memberes received academic stipends and long-term disability coverage, and brought a focus on surgical education. Reznick also fostered the growth of interdisciplinary practices, including the establishment of a university-based spine program with joint leadership by orthopedics and neurosurgery. Following his term as chair of surgery, Reznick became dean of the Faculty of Health Sciences at Queen's University, and president of the Royal College of Physicians and Surgeons of Canada. He is an honorary fellow of the Royal College of Surgeons of Edinburgh and the Royal College of Surgeons of Ireland.

\section{James Thomas RutKa (ChaIR, 2011-2021)}

When Reznick left for Queen's University to become dean of health sciences in 2010, David Latter, cardiac surgery, became interim chair until James Rutka was appointed as RS McLaughlin chair in 2011 (Figure 5). Rutka had completed a 10-year term as the Dan Family chair in neurosurgery and served as president of the American Association of Neurological Surgeons, and American Academy of Neurological Surgery before accepting the position. During his tenure as chair, Rutka established programs in best practices in surgery; global surgery; equity, diversity and inclusion; wellness; and late career transitioning. ${ }^{35}$ The offices of the Department of Surgery moved from the Banting Institute, where they had remained for 83 years, to the Stewart Building. Rutka became editor-in-chief of the Fournal of Neurosurgery in 2013, ${ }^{36}$ a Member of the Order of Ontario in 2015, and Officer of the Order of Canada in 2017. During his tenure, Rutka and his executive team (Figure 6) bolstered electronic communications; hired a medical illustrator; doubled annual research and advancement funding from $\$ 50$ million to $\$ 100$ million (Figure 7 and Figure 8), and from $\$ 4$ million to $\$ 8$ million, respectively; and helped to establish 12 new university/hospital chairs to a total of 71 endowed chairs

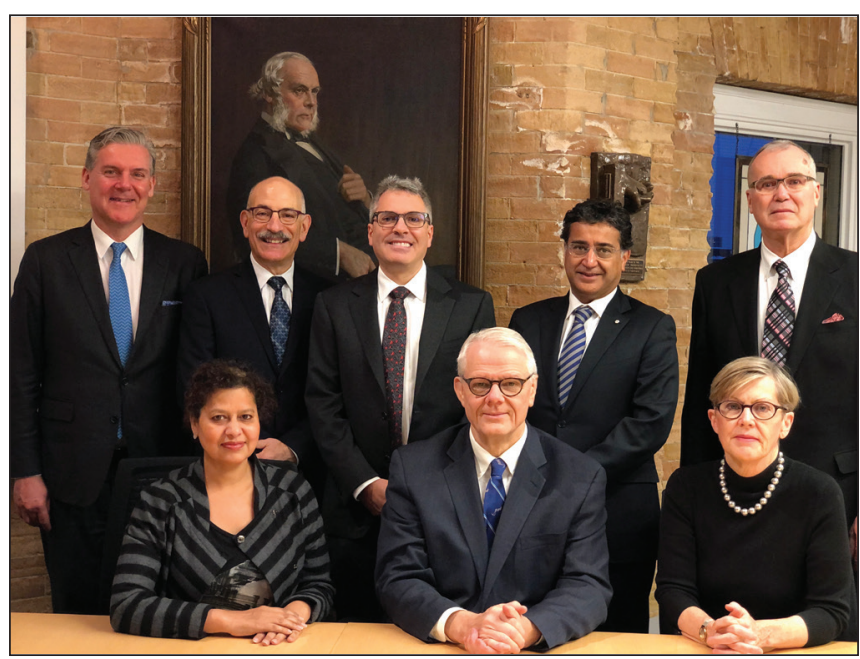

Fig. 6. Current Executive Committee of the Department of Surgery. Seated, left to right: Najma Ahmed, vice chair education, and surgeon-in-chief, Unity Health St Michael's; James Rutka, RS McLaughlin chair; Robin McLeod, vice chair best practices, past president American Surgical Association. Standing, left to right: Michael Fehlings, vice chair research; Ori Rotstein, associate chair Department of Surgery, director St Michael's and Li Ka Shing Research Institute; Avery Nathens, vice chair global surgery, surgeon-in-chief, Sunnybrook Health Sciences Centre; Shaf Keshavjee, vice chair innovation, surgeon-in-chief, University Health Network, president, American Association for Thoracic Surgery; and Robin Richards, vice chair clinical, evaluations and awards, emeritus professor orthopedics. Photo courtesy of Mrs. Sylvia Perry, Department of Surgery, University of Toronto.

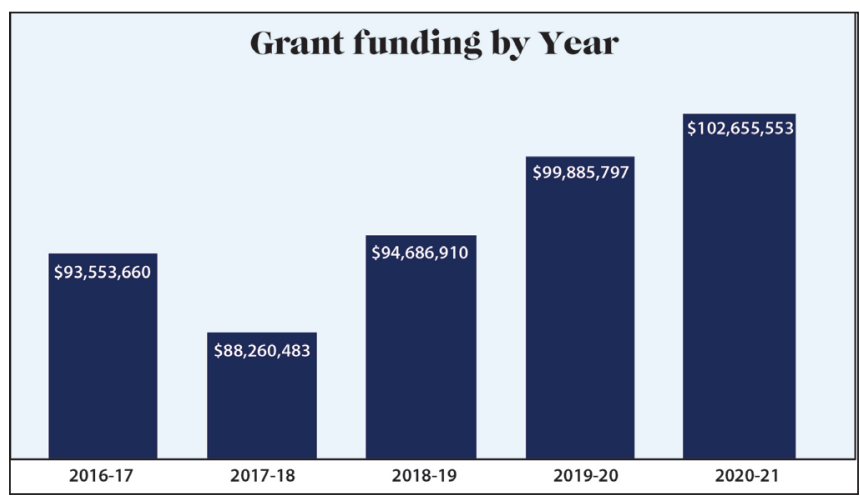

Fig. 7. Research funding, Department of Surgery, University of Toronto, 2016-21. For the past 5 years, the average annual peer-reviewed grant capture by members of the department is $\$ 96$ million.

in the Department of Surgery. New academic job descriptions were developed for surgeons with interests in ethics, global health, and entrepreneurship. Rutka also led the department through the years of the COVID-19 pandemic (2020-2021). As in years past when the department hosted national surgical groups to hold their annual meetings in Toronto, the Department of Surgery played host to the United Kingdom Traveling Society in 2016 (Figure 9). In each of the past 2 years, the Department of Surgery has ranked fourth in the world by the US News and World Report. 


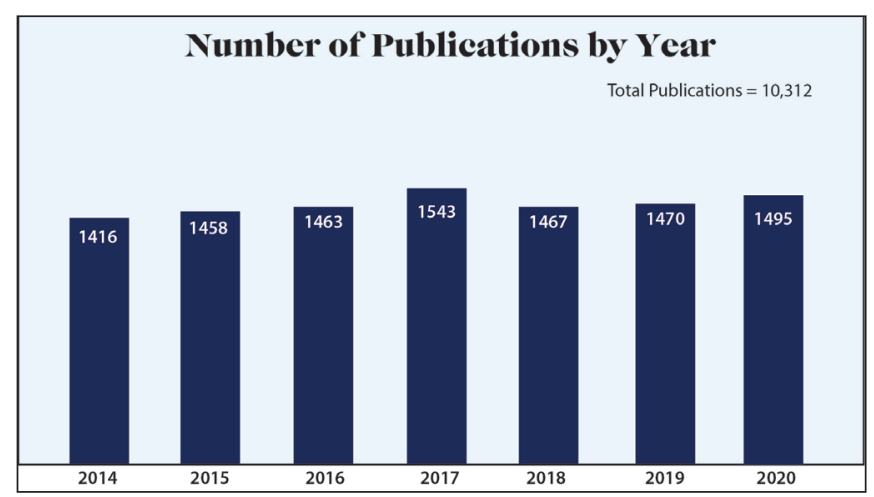

Fig. 8. Annual publications, Department of Surgery, University of Toronto. From 2014 to 2020, the department has more than 10000 peer-reviewed publications, with an average annual publication rate of 1472 papers.

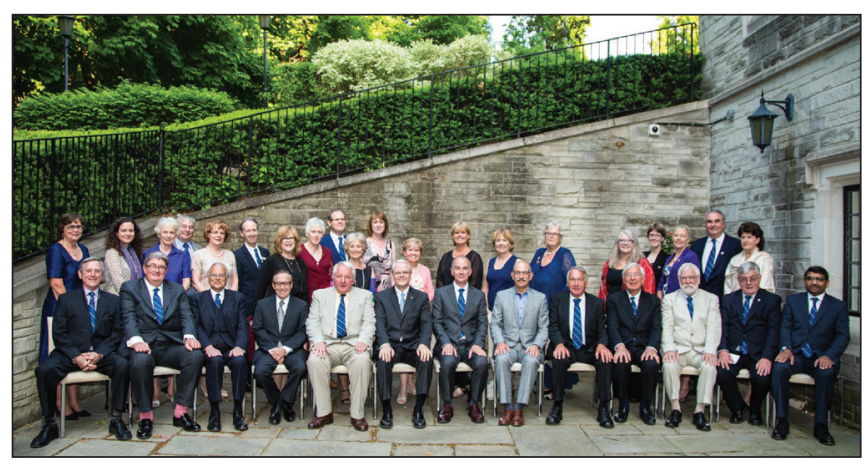

Fig. 9. Annual meeting of the United Kingdom Traveling Surgical Society, Toronto, June 3-11, 2016, Vaughan Estates, Sunnybrook Health Sciences Centre. Mr Terry Irwin, Center, presiding as president. Photo courtesy of Mr. Brian Ellis, Secretary, UK Travelling Surgical Society, 2016.

\section{Conclusion}

The Department of Surgery at the University of Toronto has enjoyed a rich history with contributions to virtually all surgical specialties through its talented faculty and highly structured and successful training programs. Each of the 10 chairs has led change and encouraged excellence in academic surgery. The research enterprise has expanded beyond basic and medical science to now include clinical epidemiology, surgical education, quality improvement, and health services. Pioneers in surgery, including Sir Frederick Banting, Gordon Murray, Kenneth McKenzie, William Mustard, William Bigelow, Griff Pearson and others too numerous to mention here within the pages of this discussion, have helped shape their respective specialties at the University of Toronto and worldwide. The research enterprise has expanded beyond basic and medical science to now include clinical epidemiology, surgical education, quality improvement, and health services research. With expanding programs in global outreach, best practices, surgeon wellness, and diversity, the future of the Department of Surgery continues to be bright.
Affiliations: From the Department of Surgery, Temerty Faculty of Medicine, University of Toronto, Toronto, Ont.

Competing interests: None declared.

Contributors: All authors contributed substantially to the conception, writing and revision of this article and approved the final version for publication.

Content licence: This is an Open Access article distributed in accordance with the terms of the Creative Commons Attribution (CC BYNC-ND 4.0) licence, which permits use, distribution and reproduction in any medium, provided that the original publication is properly cited, the use is noncommercial (i.e., research or educational use), and no modifications or adaptations are made. See: https://creativecommons. org/licenses/by-nc-nd/4.0/

\section{References}

1. Shorter E. Partnership for Excellence: Medicine at the University of Toronto and Academic Hospitals. Toronto: University of Toronto Press; 2013.

2. Gallie WE. George Armstrong Peters (as I remember him). Can $\mathcal{F}$ Surg 1959;2:119-22.

3. Peltier LF. Acute hematogenous osteomyelitis: Clarence L. Starr (1868-1928): orthopedic infections. Clin Orthop Relat Res 2002;403:3-7.

4. Stevenson L. Sir Frederick Banting. Toronto: Ryerson Press; 1946.

5. Bliss M. Getting out of town. Can Med Assoc 7 1984;130:1215-23.

6. Istl AC, Gray DK, Roscoe R. Graham: an enduring legacy in the 21st century. 7 Trauma Acute Care Surg 2017;82:216-20.

7. Istl A, Gray DK. Graham: An enduring legacy in the 21 st century. 7 Trauma Acute Care Surg 2017;82:216-20.

8. Botterell EH. Kenneth George McKenzie, MD, FRCSC, $1923-$ 1963. Surg Neurol 1982;17:81-9.

9. Morley TP. Biographical sketch of Kenneth G. McKenzie (18921964). 7 Neurosurg 2000;93:518-25.

10. Morley TP. Kenneth George McKenzie: And the Founding of Neurosurgery in Canada. 1st ed. Toronto: Fitzhenry and Whiteside; 2003.

11. Rossitch E Jr, Khoshbin S, Black PM, et al. Kenneth McKenzie, Harvey Cushing, and the early neurosurgical treatment of spasmodic torticollis. Neurosurgery 1991;28:278-82.

12. Gallie WE. Tendon fixation in infantile paralysis: observations based on one hundred operations. Ann Surg 1915;62:481-7.

13. Gallie WE. Bone wedging - a method of eliminating the introduction of foreign materials in open operations on fractures. Can Med Assoc 7 1915;5:110-2.

14. Gallie WE, Lemesurier AB. The late results of the living suture operation in ventral and inguinal hernia. Can Med Assoc 7 1930;23:165-8.

15. Dossani RH, Shaughnessy J, Kalakoti P, et al. William Edward Gallie (1882-1959): father of the Gallie wiring technique for atlantoaxial arthrodesis. 7 Neurosurg 2018;128:938-41.

16. Harris RI. William Edward Gallie, 1882-1959: an appreciation. Can Med Assoc 7 1959;81:766-70.

17. Laird RC. William Edward Gallie. Surgeon. Seeker. Teacher. Friend. Toronto: Toronto Press; 1978.

18. Robertson H. Driving Force: The McLaughlin Family and the Age of the Car. Toronto: McClelland \& Stewart Inc.; 1995.

19. McKellar S. Surgical Limits: The life of Gordon Murray. Toronto: University of Toronto Press.; 2003.

20. Murray DW. A method of palliative treatment of carcinoma of the oesophagus. Can Med Assoc 7 1931;25:271-5.

21. Murray DW. Bone graft for non-union of the carpal scaphoid. $\mathrm{Br} \mathcal{F}$ Surg 1934;22:63-8.

22. Murray GD, Best CH. The use of heparin in thrombosis. Ann Surg 1938;108:163-77.

23. Murray G. Experiments in immunity in cancer. Can Med Assoc 7 1958;79:249-59. 
24. Delaney RJ. Dr. Robert Meredith Janes (1894-1966): professor of surgery, University of Toronto (1947-1957). Can 7 Surg 1969;12:2-11.

25. O'Brien SE, Carrie AW, Palmer CR. The Janes Surgical Society. Can 7 Surg 1999;42:310-2.

26. Bigelow WG. Cold hearts. The story of hypothermia and the pacemaker in beart surgery. Toronto: McLelland and Stewart Limited.; 1984.

27. Mustard WT, Keith JD, Trusler GA, et al. The surgical management of transposition of the great vessels. 7 Thorac Cardiovasc Surg 1964:48:953-8.

28. Pearson FG. Frederick Gordon Kergin, 1907-1974. Can 7 Surg 1975;18:109-10.

29. David TE. Surgical treatment of aortic valve disease. Nat Rev Cardiol 2013;10:375-86.

30. David TE, Feindel CM, David CM, et al. A quarter of a century of experience with aortic valve-sparing operations. 7 Thorac Cardiovasc Surg 2014;148:872-9, discussion 879-80.
31. David TE, Ivanov J, Armstrong S, et al. Late outcomes of mitral valve repair for floppy valves: implications for asymptomatic patients. 7 Thorac Cardiovasc Surg 2003;125:1143-52.

32. Deslauriers J, Pearson FG, Nelems B. Evolution of thoracic surgery in Canada. Can Respir 7 2015;22:72.

33. Knupfer MM, Poppenborg H, Hotfilder M, et al. CD44 expression and hyaluronic acid binding of malignant glioma cells. Clin Exp Metastasis 1999;17:71-6.

34. Zuo KJ, Meng Y, Gordon L, et al. Navigating the postgraduate research fellowship: a roadmap for surgical residents. 7 Surg Res 2020;256:282-9.

35. Richards R, McLeod R, Latter D, et al. Toward late career transitioning: a proposal for academic surgeons. Can 7 Surg 2017;60:355-8.

36. Rutka JT. Leading transition while maintaining tradition. 7 Neurosurg 2013;119:1-3. 